\title{
ОСОБЛИВОСТІ ОРГАНІЗАЦІЇ ФІЗИЧНОЇ ПІДГОТОВКИ І ПОЗАКЛАСНОЇ РОБОТИ В КАДЕТСЬКИХ КОРПУСАХ У ХІХ - НА ПОЧАТКУ ХХ СТОЛІТТЯ
}

Кормілець С. В. Особливості організації фізичної підготовки і позакласної роботи в кадетських корпусах у XIX - на початку XX століття.

Статтю присвячено дослідженню питань, пов'язаних з організацією фізичної підготовки й фізичного розвитку учнів кадетських корпусів Російської імперії на територіях українських губерній у XIX - на початку XX сторіччя. Показано основні етапи становлення й розвитку системи тілесних вправ, які сприяють удосконаленню фізичного розвитку кадетів, майбутніх офіцерів. Розкрито деякі аспекти проведення позакласної роботи в кадетських корпусах.

Ключові слова: кадетські корпуси, кадети, військово-навчальні заклади, військово-фізичні вправи, тілесні вправи, фізична підготовка, гімнастика, позакласна робота.

Кормилец С. В. Особенности организации физической подготовки и внеклассной работы в кадетских корпусах в XIX - вначале XX века.

Статья посвящена исследованию вопросов связанных $\mathrm{c}$ организацией физической подготовки и физического развития учеников кадетских корпусов Российской Империи на территориях украинских губерний в XIX - начале XX столетий. Показаны основные этапы становления и развития системы телесных упражнений, способствующих усовершенствованию физического развития кадетов, будущих офицеров. Раскрыты некоторые аспекты проведения внеклассной роботы в кадетских корпусах.

Ключевые слова: кадетские корпуса, кадеты, военно-учебные заведения, военно-физические упражнения, телесные упражнения, физическая подготовка, гимнастика, внеклассная робота.

Kormilets S. V. Features of physical fitness and extracurricular activities in the cadet corps: in the nineteenth to early twentieth century.

The article is devoted to the study of issues related to the organization of fitness and physical development of students of cadet's schools in the territories of the Russian Empire in the Ukrainian region of the XIX - early XX centuries. The basic stages in the development of the system of physical exercises contribute to the improvement of the physical development of cadets, the future officers. Discloses certain aspects of afterschool club in military schools.

Key words: cadet, cadet's schools, military schools, military exercise, physical exercise, physical fitness, gymnastics, after-school club.

Основне завдання сучасної освіти - виховання освіченого, фізично здорового громадянина, який у будь-який час був би готовий захищати свою Батьківщину, збільшувати блага сучасного суспільства, бути гідним громадянином своєї держави. Саме такі завдання 3 давніх часів розв'язувалися традиційно і нині розв'язуються в Кадетському корпусі та військових ліцеях України.

Вимоги сучасного етапу розвитку українського суспільства зумовлюють необхідність подальшого реформування системи загальної освіти. Основні напрями цього процесу визначено у найважливіших документах: Державній національній 
програмі «Освіта», Законі «Про освіту», «Про загальну середню освіту», «Національній доктрині розвитку освіти у XXI столітті», Державному стандарті загальної освіти. Значний інтерес становить унікальний досвід, накопичений кадетськими корпусами, які зараз переживають друге народження, і спрямовують свою роботу на надання базової та повної загальної середньої освіти відповідно до Державних стандартів загальної середньої освіти, виховання громадянина України на кращих традиціях українського народу самовідданого служіння Україні, готовності до захисту тї незалежності і територіальної цілісності, поваги до Конституції України, державних символів України, почуття власної гідності, відповідальності перед законом за свої дії.

Вивчення позитивного досвіду організації навчально-виховної роботи в кадетських корпусах Російської імперії, створених на територіях українських губерній у період XIX - початку XX століття, аналіз програм, форм, методів і засобів навчання має велике значення задля якісного керівництва процесом відродженням цих закладів освіти в незалежній Україні.

Проблеми, пов’язані з підготовкою майбутніх офіцерів у кадетських корпусах, розглядались у роботах вітчизняних та зарубіжних науковців Ю. Ільїна, О. Клімашкіної, О. Ніколаєва, В. Самусенка, В. Свиридова, Д. Сімашенкова, В. Струтинського, О. Сушанського, С. Федоріна. Загальний історіографічний огляд засвідчив, що проблема формування і розвитку кадетських корпусів на території України не була об'єктом самостійного дослідження і не отримала системного відображення в історіографії.

Mema cmammi- здійснити науково-теоретичний аналіз розвитку системи кадетської освіти в Російській імперії й на територіях українських губерній у XIX на початку XX сторіччя; схарактеризувати структуру військово-фізичної підготовки кадетів і методи організації позакласної роботи в кадетських корпусах.

Навчальні заклади інтернатного типу, що готують своїх вихованців до військової служби, мають на меті всебічний фізичний розвиток учнів і організацію занять, які могли б плідно, у виховному аспекті, заповнити дозвілля вихованців.

«Настанову для позакласних занять» розроблено в 80-ті роки, затверджено головним начальником військово-навчальних закладів у 1890 році.

Вправи й заняття, наведені в Настанові, для кадетських корпусів, складаються з таких відділів:

- стройове навчання і військово-підготовчі заняття;

- фізичні вправи: гімнастика й рухливі ігри; фехтування; плавання; танці;

- спів і музика;

- ручна праця.

Із названих занять: стройове навчання, усі фізичні вправи й хоровий спів обов'язкові для всіх кадетів; музика й ручна праця для всіх не обов'язкові, вихованці, у яких $є$ хист до музики, навчаються грі на інструментах; інші - відповідно до оснащення закладу й інших умов залучаються до навчання ручної праці.

На ці заняття передбачено таку кількість часу:

На гімнастику - від 3 до 4 год на тиждень.

\begin{tabular}{|l|l|l|}
\hline фізичні вправи & 1 & 2 \\
\hline танці & 1 & - \\
\hline спів & 2 & - \\
\hline музика & 3 & - \\
\hline ручна праця & 3 & - \\
\hline
\end{tabular}

Педагогіка вищої та середної школи. - 2014. - Вип. 40. 
Фехтуванням займаються тільки кадети старших рот поурочно, не менше двох уроків на тиждень.

Щодня кадети мають не менш 1 години систематичних тілесних вправ.

Тілесні вправи, названі гімнастикою, внесено до змісту навчання в кадетських корпусах ще в 1832 р. 3 особистої ініціативи Головного начальника військовонавчальних закладів Великого Князя Михайла Павловича. Це була шведська гімнастика, і відповідальним за викладанням у всіх корпусах був швед.

Кадетські корпуси були чи не першими військово-навчальними закладами у всій Європі (крім Швеції), у яких були введені систематичні заняття з гімнастики. У Німеччині цього періоду не викладали шведської гімнастики, а до системи, запропонованої Яновським, ставилися 3 недовірою 3 політичних міркувань i перешкоджали запровадженню їі в школу.

Із тих пір гімнастика викладається в наших кадетських корпусах із змінним успіхом, певними видозмінами в системі.

Виникає безліч запитань, чому військово-навчальне відомство не відмовилося від гімнастики. Скажемо коротко, що погляд його на гімнастику збігся 3 поглядом французької комісії, що обговорювала тоді ж питання про гімнастику під головуванням знаменитого професора Марея. Ми говоримо: збігся, а не запозичений, тому що остаточний результат праць комісії професора Марея (підручник) виданий у 1891 р., а Настанова затверджена в 1890 р.

У Франції, так само, як і в системі вітчизняної освіти, гімнастику було дискредитовано свавільним викладанням. Проте, відповідно до обговорення питання про цілі й засоби гімнастики комісія доктора Марея формулювала свої остаточні положення так: «С два методи фізичного виховання: один, який можна назвати класичним, рекомендує гімнастику у власному розумінні слова, що полягає в регульованих рухах і вправах на снарядах. Інший - у використанні вільних вправ $і$ вправ на розвиток сили і спритності, що виконуються на свіжому повітрі. Кожний із цих методів має свої переваги, але кожний 3 них, використовуваний окремо, недостатній задля досягнення передбачуваної мети, що полягає в гармонійному розвитку, заради практичної користі, усіх фізичних і моральних сил людини. Істина, як це буває майже завжди, перебуває між двома системами, і рішення завдання полягає в запозиченні з кожної з них того, що в них $\epsilon$ найкращого, у комбінації їх й усуненні з них усього зайвого».

Саме 3 огляду на подібні міркування військово-навчальне відомство встановило в кадетських корпусах викладання гімнастичних вправ із рухливими іграми. Щодо системи вправ було обрано найбільш правильний шлях, на його думку: не приймаючи ризикованих завдань щодо створення нової системи і не знаходячи можливості використання будь-якої із найбільш розроблених іноземних систем (шведської або німецької), з усіма їхніми національними особливостями, воно дозволило користуватися всім тим, що на сучасному етапі гімнастики на Заході може бути визнаним найбільш доцільним для закритих навчальних закладів загалом і для кадетських корпусів - зокрема. Спочатку такий метод може бути використаний тільки в освітній еклектичній системі; а за розумного вдосконалення його досвідченими й інтелігентними вчителями він, безсумнівно, має слугувати підгрунтям для поступового виникнення самостійної російської системи гімнастики.

Програма 3 гімнастики описана в Настанові тільки загалом. Із 1890 р. ця програма поступово розроблялася практично, вона може бути витлумаченою так: головне завдання педагогічної гімнастики, якщо вона викладається разом із 
рухливими іграми, полягає у прищепленні вихованцям правильних положень i рухів, що безпосередньо суперечать тим несприятливим умовам для нормального фізичного розвитку, у яких перебуває вихованець під час своїх навчальних занять у класі. Одними іграми це завдання не може бути розв'язане.

3 огляду на ці міркування розрахована більшість форм гімнастичних положень і рухів: а) тільки таке гімнастичне положення вважається правильним, яке створює повну свободу диханню; б) в основному положенні - стоячи - потрібно злегка розвести носки в боки, пряме положення голови, розгорнуті й опущені плечі й таке загальне вертикальне положення тіла, при якому повна стійкість досягається 3 найменшою м'язовою напругою; в) тільки такі рухи вважаються доцільними, які $\epsilon$ симетричними за умови одночасного, поперемінного або послідовного виконання; г) введено спеціальні вправи для розвитку рухливості суглобів (шведськ. Spännböjande Rr) задля попередження кіфозних скривлень; д) вправи повинні давати достатній розвиток, але не стомлювати.

Більшість вправ цього порядку взято зі шведської гімнастики, науково обгрунтовано їх ортопедичний і гігієнічний вплив на організм.

Водночас завдання гімнастики не обмежується в кадетських корпусах тільки протидією шкідливому впливу тривалого сидіння у класах: вона повинна виконувати і позитивне завдання всебічного фізичного розвитку.

Підготовчі вправи самі по собі складають основу для фізичного розвитку, але не виконують цього завдання.

Під фізичним розвитком розуміється розвиток тих загальних здібностей рухового апарату, які необхідні людині в будь-якому виді діяльності, які людина інстинктивно виконує 3 дитинства, необхідні для здоровішої життєдіяльності організму [4]. Ці вправи суттєво відрізняються від професійних видів фізичної діяльності, оскільки кінцева їх мета - розвиток самої людини, а не зовнішній результат роботи. Звичайно, навіть раннє залучення до професійної роботи несприятливо впливає на розвиток цих загальних здібностей.

До таких загальних вправ належать: 1) вправи у стійких положеннях тіла при різних видозмінах точки опори; 2) вправи в роботі верхніх кінцівок: брати, хватати, кидати, ловити тощо, при різних положеннях: згинання, витягування, приведення i відведення рук; 3 ) вправи 3 ходьби, бігу, стрибків; 4) вправи на рівновагу; 5) вправи в подоланні різного роду перешкод за допомогою стрибків; 6) згинання та розгинання рук в упорі; 7) вправи з боротьби і взагалі в протидії зовнішній живий силі; 8) деякі спеціальні вправи, що сприяють покращенню самопочуття; 9) різні комбінації всіх цих родів вправ.

Наведено схему вправ, яка, за деякими винятками, рівною мірою належить i німецькій, і шведській гімнастиці, але різні відділи цієї схеми виконуються не 3 однаковою повнотою в обох цих системах. Тому військово-навчальне відомство задля досягнення можливої завершеності загальноосвітнього курсу гімнастики в багатьох випадках користується німецькими різноманітними вправами, які можуть зацікавити вихованців; загальний же метод викладання скоріше наближається до шведського методу, педагогічної гімнастики.

Варто особливо вказати на те, що всі перераховані роди вправ не становлять матеріалу, що винятково належить до гімнастики. Це ті ж вправи, які входять і до рухливих ігор, і до інших видів спортивної діяльності.

Гімнастика відрізняється від вправ спортивно-прикладного характеру й рухливих ігор не родами вправ, а тільки методом їх викладання. 
Головна особливість методу педагогічної гімнастики (i саме шведської) полягає в поділі вправ на роди й типи.

Роди або типи вправ приблизно відповідають тим групам, які зазначені у вищенаведеній схемі. Так, усі вправи на рівновагу становлять свій особливий рід вправ; перенесення вантажу, стрибки, лазіння, ходіння й біг, усе це особливі роди вправ.

У кожному роді, або типі вправи підрозділяються на види, відповідно до їхньої складності, починаючи від самих елементарних і поступово наближаючись до більш складних. Так, перенесення ваги тіла на одну з ніг при положенні стоячи становить один 3 елементарних видів вправ на рівновагу, незначне згинання рук з подоланням якого-небудь зовнішнього опору буде елементарною вправою для лазіння.

Унаслідок великої різноманітності вправ у формах i характері точне розмежування між родами вправ, з одного боку, і типами - 3 іншого, не завжди $€$ можливим. Розроблено багато вправ, особливо найпростіших, які можна віднести й до того й до іншого роду, але це анітрохи не порушує значення такої класифікації задля вправ відповідно до віку, сили і загального фізичного розвитку учнів.

Роди або типи вправ не порівнювані між собою за ступенем складності, тому, що кожний з них відноситься до особливої здатності рухового апарату, так і тому, що кожний з них може бути представлений у найелементарніших вправах. Але саме 3 цих причин 3'ясовується, що всі роди вправ доступні для учнів навіть на найнижчому щаблі їх розвитку. Якщо тут i можуть бути винятки, то досить незначні: опорні стрибки, згинання та розгинання рук в упорі від підлоги тощо. Але й ці вправи становлять лише більш складні види стрибків і висів.

На цій підставі кожний урок гімнастики або система уроків заради всебічного впливу вправ повинен містити всі роди вправ, що доступні для учнів.

Задля градації вправ відповідно до сили учнів враховуються такі підстави:

- порівняльна простота форм у положеннях і рухах; плавність;

- порівняльна простота в характері виконання: швидкість, повільність,

- більша або менша напруженість вправ;

- більша або менша тривалість вправи;

- число повторювальних рухів;

- вимога більшої або меншої точності у виконанні (діти взагалі менш здатні до точності, ніж дорослі).

Загалом, під час викладання гімнастики слід прагнути не стільки до розвитку сили, скільки до розвитку здатності точної й вільної координації рухів і витривалості, тобто здатності до тривалої роботи. Місцевий вплив вправи, що виражається в силі м'язів, є результатом усебічного розвитку, оскільки цей вплив повинен відповідати природним задаткам організму.

Якщо говорити про гімнастику 3 погляду прищеплення певних навичок, то метод iï не можна назвати емпіричним. Він такою ж мірою логічно обгрунтований, як і метод будь-якого іншого навчального предмета.

Що стосується гігієнічного й місцевого впливу тієї або іншої вправи, то це питання, звичайно, ще не досить розроблене. Але цей недолік такою ж мірою поширюється на всі інші тілесні вправи, як і на гімнастику. Не говорячи вже про ремісничі заняття, ігри i, особливо спортивні вправи, що становлять суперечливий їх вплив на здоров’я й розвиток учнів. Щодо цього гімнастика стоїть на щабель 
вище, тому що шведи зробили більші успіхи в оцінці гігієнічного, особливо місцевого впливу вправ на організм людини.

У кадетських корпусах урок гімнастики, на якому вихованці вивчають нові вправи й повторюють вивчені раніше, представлені інакше, гімнастичні вправи гігієнічного характеру проводяться ввечері, після закінчення всіх денних навчальних занять, протягом години або 20 хв. У цей час зазвичай, проводяться тільки найпростіші рухи, що не вимагають складної координації, не стомлюють, добре відомі вихованцям і спрямовані на відновлення рухових функцій після довгого примусового сидіння і розумової роботи.

Для більш суворого контролю методичної послідовності вправ на уроках викладач гімнастики веде журнал. У всіх випадках, коли під час викладання гімнастики потрібно звернути увагу на індивідуальні особливості учня, необхідно враховувати його морфофізіологічні особливості, спираючись на висновок лікаря.

Про гімнастику нерідко говорять, що вона стомлююча й нудна.

Без сумніву, як заняття обов'язкове, вона може бути стомлюючою. Водночас це вже залежить не від гімнастики, а від способу їі викладання. За величезної різноманітності гімнастичних вправ є завжди можливість чергувати важкі види 3 більш легкими, і саме такими, які могли б сприяти відновленню організму після стомлюючої роботи. Шведи називають такі вправи «деривативними». Думка, що гімнастичні вправи становлять лише нове фізичне навантаження після розумової втоми від навчальної роботи, не виправдовується життєвою практикою. Той, хто хоч раз у житті займався тілесними вправами, знає, який оздоровчий вплив мають ці вправи після розумової праці, особливо, коли вони безпосередньо протидіють вимушеній нерухомості в сидячому положенні й розвантажують стомлену увагу.

Гімнастика може бути також і нудною. Можна навіть сказати, що вона здебільшого $є$ нудною в тому вигляді, у якому вона й дотепер ще іноді викладається в нас вчителями-рутинерами. Шеренга $з$ тридцяти людей перед одним снарядом, де кожний томливо чекає своєї черги, - це дуже нудно. Ще більш нудні вільні вправи, що виконуються монотонно.

Але гімнастика може бути також і не нудною, кращим свідченням тому слугують численні й багатолюдні гімнастичні суспільства Німеччини й Швеції. Без сумніву, в цих країнах люди збираються не для того, щоб нудьгувати. Якщо до цього додати, що вони захоплюються гімнастикою зі шкільної лави, то, звичайно, вони й у школі не нудьгували на цих заняттях. Усе залежить від способу викладання вправ. Віра вчителя у свою справу, його особиста відданість, його технічна вмілість, належна кількість і зручність усіх приладів, пробудження в учнів змагальної діяльності, - усе це дуже важливі засоби для того, щоб заохотити вихованців до занять вправами.

Саме до такої постановки гімнастики і прагнуть у кадетських корпусах. Окрім вказівок, у Настанові 3 цього приводу $є$ кілька спеціальних наказів головного начальника військово-навчальних закладів.

Щодо викладання рухливих ігор відомство військово-навчальних закладів зробило крок уперед у тому відношенні, що розвиток ігор у середовищі вихованців не має тільки випадковості. По-перше, у Настанові зазначені засоби для поширення ігор (навчання грі, вибір ігор відповідно до віку, участь керівника тощо). По-друге, ігри забезпечують зв'язок з гімнастикою й у багатьох випадках відносяться до методичних вправ, які, у свою чергу, мають характер гри. До таких належать стрибки й метання. Отже, на гру покладає частина завдань фізичної підготовки. По- 
третє, для ігор відводиться більше часу (залежно від віку вихованців і пори року), ніж для уроків гімнастики. У молодших класах ігри обов'язково проводяться на кожному уроці гімнастики: ними завершується урок. На повітрі урок гімнастики дозволено повністю присвячувати грі.

У літньому таборі 3 години поспіль раз на тиждень даються старшим вихованцям для занять ігровими видами діяльності. При виборі ігрової діяльності віддається перевага національним іграм. За останні роки рухливі ігри помітно стали розвиватися в середовищі вихованців навіть у старших класах, чого колись не було. У провінційних корпусах, що володіють більшими ділянками землі, ігри використовуються більш активно, вони $\epsilon$ одним 3 улюблених засобів для наповнення святкового дозвілля вихованців.

Плавання, хоча й давно вже викладається в деяких кадетських корпусах, стало обов'язковим предметом навчання тільки із уведенням у дію «Настанови для позакласних занять». Щодо значення цього відділу вправ як освітнього й гігієнічного засобу не може бути розбіжностей, а тому ми й зупинятися на цьому не будемо; зазначимо тільки, що плавання має велике значення для майбутнього військового. У цей час у кадетських корпусах усі вихованці старших рот обов'язково навчаються плаванню за певною системою. Результати оволодіння цим видом не скрізь однакові залежно від кліматичних умов, обладнання водних басейнів тощо; але є заклади, у яких навчання плавання здійснюється на високому рівні. У Київському корпусі функціонує великий штучний басейн, у якому вихованці можуть брати уроки плавання у зимовий час.

Фехтування й танці. Ці предмети введено до програми кадетських корпусів 3 моменту їх внесення до освітньої системи на початку XIX сторіччя. Мала місце короткочасна перерва протягом 15-20 років для фехтування.

Якщо звернути увагу на історію цих тілесних мистецтв, можна зробити висновок, що після тривалого процвітання у всій Європі, особливо протягом XVIIIпоч. XIX ст., як вправи, необхідні для світської людини, вони дещо втратили значення педагогічних занять і поступилися місцем іншим вправам. Але це не означає, що вони зовсім зійшли зі сцени. Фехтування стало військово-підготовчим мистецтвом i в цьому напрямку активно розвивалося. Танцям, якщо їх не викладають у школі, учні переважно навчаються приватно.

У кадетських корпусах фехтування викладається не тільки тому, що майбутньому офіцерові необхідно вміти володіти зброєю, яку він буде мати завжди при собі, але й тому, що фехтування як різновид єдиноборства характеризується умовними етичними й естетичними вимогами, розвиває у юнаків мужність, упевненість у своїх силах, повагу до супротивника. Як фізична вправа воно становить досить важливе доповнення до систематичної гімнастики й безпосередньо може бути внесеним до системи фізичного виховання. Особливо важливе воно як вправа, у якій своєчасність, точність і швидкість рухів регулюються постійною й уважною роботою зорового органу.

Фехтування викладається в кадетських корпусах тільки для вихованців старших класів і тільки в основних своїх елементах, тому що для молодших вихованців - це важка вправа.

Танці, які викладаються в кадетських корпусах, мають мало спільного 3 тим фривольним мистецтвом, якому приватно навчається молодь у вільнопрактикуючих танцмейстерів. Про оволодіння салонними танцями за два уроки не йдеться взагалі. До V класу курс «Танці» в кадетських корпусах наближається, скоріше, до того 
відділу гімнастики, який називається «вільними вправами», 3 більш широким розвитком ритмічного боку рухів і 3 більшою увагою до естетичних умов виконання. Для такого викладання у військово-навчальному відомстві розроблено спеціальний курс, що заслуговує на увагу викладачів усіх відділів вправ. Усе, що має відношення до танцю як гаяння часу в дамському суспільстві, із цього курсу виключено, але звернено багато уваги на розвиток рухів, добірності постави тощо. Тільки у двох старших класах викладаються танці у їхньому салонному характері, переважно задля попередження приватної виучки, у якій молодь дуже часто здобуває звички досить сумнівної гідності з боку їх пристойності.

Слід зазначити, що спроби методики навчання танцям в кадетських корпусах розпочинаються ще до 40-х років XIX століття, але остаточне внесення до навчальної програми кадетських корпусів починається з затвердженням Настанови, тобто в 1890 році.

Стройові вправи. Для закладів, які готують своїх вихованців до військової служби, стройові вправи мають свій raison d'etre як підготовка до цієї діяльності.

Наведемо найбільш вагомі думки щодо виховного значення стройового навчання. Одна думка, висловлена наприкінці XVIII століття, інша - наприкінці XIX століття, але обидві є цінними 3 огляду на те, що висловлені двома майстрами тілесних вправ, людьми не військовими, але великими знавцями особливостей морфофункціонального розвитку дітей. Один з них - Гутсмутс, педагог-філантроп $\mathrm{i}$ творець нової гімнастики, інший - відомий лікар Лагранж.

«Я думаю, - говорив Гутсмутс, - що перенесення стройових вправ до щоденного режиму юнацтва $є$ корисним, як для наших виховних закладів, так і для багатолюдних родин, де немає кінця шуму, біганині й метушні, забуванню потрібних речей, безладу в одязі тощо. Приємно бачити, коли хлопчики і юнаки біжать на свої місця по команді, стають у стрій, приймають правильне положення й чітко йдуть як одне ціле в зазначене місце... Той, хто щодня має справу з багатьма молодими людьми, добре зрозуміє те, про що я говорю» [2].

«Друга підстава, що спонукує мене рекомендувати військово-прикладні вправи гімнастичного характеру, стосується покращення зовнішнього вигляду людини. Більшість юнаків украй недбало ставляться до розвитку свого тіла...» «Далі, зі мною погодяться, що молодих людей треба змалку привчати до подолання труднощів, до терпіння й загартовувати їх для майбутності; для цього теж доцільні військовоприкладні вправи... Нарешті, вони мають важливе значення для вияву мужності хлопчиків, зміцнення їхнього духу тощо. Усе це, - додає Гутсмутс, - дуже подобається хлопчикам, і коли це проводиться, без перебільшення, то вони самі просять учителя організувати їм стройове навчання».

Інший автор, доктор Лагранж, в останньому своєму, досконалому, але, на жаль, мало відомому творі - «La medication par l'ехегсісе», у статті: «Ортопедія в сім'ї», указує на вправи для корекції постави, як на один 3 наймогутніших засобів проти скривлення постави, явища настільки звичайного в сучасної молоді. У книзі, написаній після ознайомлення зі шведським методом гімнастики, доктор Лагранж $\epsilon$ рішучим прихильником цього методу не тільки для лікарських, але особливо для педагогічних цілей [1].

Зважаючи на сказане вище, можна стверджувати, що в століття загальної військової повинності, прискорених методів військового навчання, змінних вимог до військової справи, колишнє муштрування втратило своє значення не тільки у військово-навчальних закладах, але навіть і в арміях. 
Військово-навчальні заклади зобов'язані «стройовому» навчанню бадьорим виглядом своїх вихованців, їх виправкою, ознайомленням їх із зовнішніми формами військової пристойності й майже повною відсутністю юнаків 3 кіфозними, лордозними або сколіозними скривленнями. Досягається це простими вправами, нешкідливість яких для дітей гарантується тим, що вони проводяться їхніми безпосередніми офіцерами-вихователями, які відповідають за життя та здоров'я своїх вихованців.

\section{Література}

1. Бутовский А. Д. Собрание сочинений: в 4 т. / А. Д. Бутовский. - К. : Олимп. л-ра, 2009. - Т. 3 - 358 с. 2. Бутовский А. Д. Телесные упражнения и внеклассные занятия в кадетских корпусах / А. Д. Бутовский. - М., 1898. 3. Греков Ф. В. Краткий исторический очерк военно-учебных заведений 1700-1910 / Ф. В. Греков. M., 1910.

УДК 37 (013)

Валерія Устименко

\section{УПЛИВ СОЦІЛЬНО-ПОЛІТИЧНИХ ЧИННИКІВ НА ФОРМУВАННЯ БАГАТОМОВНОСТІ В КАНАДІ}

Устименко В. В. Уплив соціально-політичних чинників на формування багатомовності в Канаді.

У статті розглянуто поняття двомовності та багатомовності як важливі аспекти соціально-політичного життя в Канаді. Основну увагу приділено причинам виникнення та етапам розвитку багатомовності.

Ключові слова: Канада, офіційна мова, офіційна двомовність, білінгвізм, багатомовність, мультилінгвізм.

Устименко В. В. Влияние социально-политических факторов на формирование многоязычия в Канаде.

В статье рассматриваются понятия двуязычия и многоязычия как важные аспекты социально-политической жизни в Канаде. Основное внимание уделяется причинам возникновения и этапам развития многоязычия.

Ключевые слова: Канада, официальный язык, официальное двуязычие, билингвизм, многоязычие, мультилингвизм.

Ustimenko V. V. Influence of socio-political factors on multilingual formation in Canada.

The article examines the notions of bilingualism and multilingualism as important aspects of modern socio-political life in Canada considering globalization and mankind transition to information society; the most favorable conditions for bilingualism and multilingualism emergence are defined. The focus is on reasons of emergence and stages of multilingualism development in Canada.

Key words: Canada, official language, official bilingualism, bilingualism, multilingualism.

Політичні та суспільні зміни, які відбуваються в сучасному світі, 3 притаманними йому інтеграцією та глобалізацією, як всесвітньою багаторівневою мережею найрізноманітніших зв'язків та високим рівнем розвитку технічних 